\title{
Molecular Insights into Bromelain Application in Industry and Health Care
}

\author{
Sushma S. Murthy and T. Bala Narsaiah \\ ${ }^{1}$ Research Scholar, Department of Chemical Engineering, JNTUA College \\ of Engineering, Ananthapuram-515002, Andhra Pradesh, India \\ ${ }^{2}$ Department of Chemical Engineering, JNTUA College of Engineering, \\ Ananthapuram-515002, Andhra Pradesh, India
}

\section{ABSTRACT}

Bromelain is a cysteine protease derived from the stem and fruit of the pineapple. It has a significant role in pharmacological and clinical applications. Studies have shown Bromelain to be a potent photoactive compound that has a wide application in industry. It has also been shown to be effective in treatment of cancer, inflammation, and allergies. It has a distinct immunomodulatory activity which forms an important strategy in its utilization as a therapeutic agent. Bromelain plays a significant role at molecular level by regulating the expression of proteins that are potential therapeutic targets. Bromelain is used extensively worldwide as an herbal medicine as it promises good efficacy and has no side effects. This paper reviews the general characteristics of Bromelain, its separation process, and its use in industries and healthcare as a therapeutic agent. The present review identifies that there is lack of knowledge pertaining to the mode of action of Bromelain in inhibiting transcriptional factors and in controlling cancer. An in-detail analysis in this area might help in expanding the therapeutic scope of Bromelain.

KEY WORDS: BROMELAIN, CANCER, PHARMACOLOGICAL ACTIVITY, SEPARATION, TRANSCRIPTION FACTORS.

\section{INTRODUCTION}

The Bromelain protease is isolated from the stem and fruit of Pineapple (Ananas comosus,). Pine apple belongs to the family Bromeliaceae. It finds extensive utilization in tropical and subtropical countries. Bromelain is a sulfhydryl activated protease enzyme (EC 3.4.22.32). Since 1875 , without proper scientific evidence, bromelain has been widely used by the tribal community and natural healers in its crude extract form to treat various health issues. The enzyme is also used as dietary supplement

\section{ARTICLE INFORMATION}

Received 29th Oct 2020 Accepted after revision 21st Dec 2020 Print ISSN: 0974-6455 Online ISSN: 2321-4007 CODEN: BBRCBA

Thomson Reuters ISI Web of Science Clarivate Analytics USA and Crossref Indexed Journal

\section{Clarivate
Analytics}

NAAS Journal Score 2020 (4.31)

A Society of Science and Nature Publication,

Bhopal India 2020. All rights reserved.

Online Contents Available at: http//www.bbrc.in/

Doi: http://dx.doi.org/10.21786/bbrc/13.15/8 because of its wide benefits to the human system. The stem part of the plant, which is inexpensive and is usually discarded, has a high concentration of bromelain and forms an important raw material for the isolation and purification of the enzyme. The growing demand for pineapple has led to high disposal of its stems, which can instead be reused in an innovative and scientific way. Due to the significant role of the enzyme in food, textile, dairy, healthcare industries, the pineapple stems have formed an excellent raw material for extraction of the enzyme, thereby avoiding large-scale wastage and environmental pollution.

Bromelain has been found to be useful in treatment of platelet aggregation, traumas, bronchitis, thrombophlebitis, and angina pectoris. Bromelain is used as anti-inflammatory and anti-cancer agent. It is useful in treatment of bronchitis and allergic air-way diseases. The enzyme upon the administration via the oral route is easily absorbed from the human intestine without undergoing any significant changes and retains

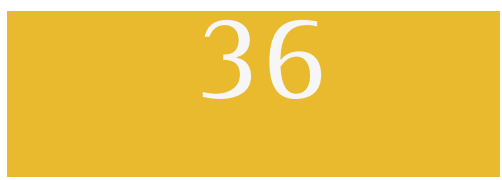


its physical and biological properties. The significant and ample application of bromelain in industry and health care forms an important aim in the research area for potential exploration of the molecule as shown in Figure 1.

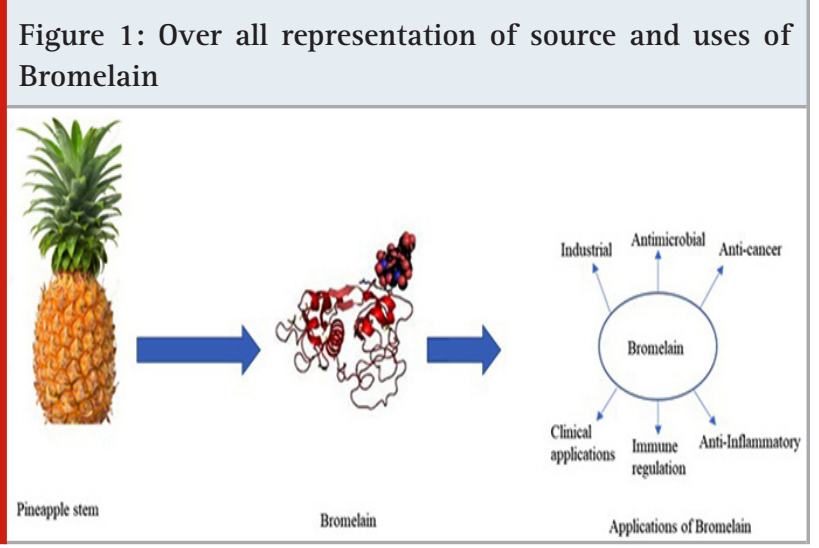

Separation Stratergies and Biochemistry of Bromelain: The demand for bromelain due to its extensive application in clinical research and other industries emphasizes the need for developing high throughput technology for its separation and purification. The main strategy of purifying bromelain effectively is to obtain a high fold of purification, along with a high percentage of product recovery. Thus, the main objective of the researcher should be to shorten the purification process, thereby reducing the associated cost and time.

The chromatographic separation of bromelain using different column matrices such as CM Sephadex, and DEAE sephacel 6, showed six fractions namely SBB1, SBB2, SBB3, SBB4, SBB5, and SBA which contain the enzyme. These fractions migrated as a single band on SDS gel electrophoresis with different migration rates revealing their difference in molecular weights. Sequencing of the enzyme by cyanate method showed that the amino terminal position of fractions SBB 1-5 and SBA have valine. Sequencing post hydrazinolysis showed that carboxyl terminal had glycine residue in SBB 1-3, SBA and serine in SBB4 and SBB5 fractions. Of the various fractions tested for enzymatic activity SBB4 and SBB5were more active than the other fractions [5]. Recently, there is an increased demand for novel separation and purification techniques that involve fewer steps in the separation and purification process and offer a higher product-recovery percentage.

Aqueous two-phase extraction is a liquid-liquid extraction method shows a fold purification of 16.3 and recovery of 55.6\%. The method requires minimum inputs of time and energy and gives maximum yield at the end of the process. It is a low-cost process that can be scaled up with ease. The purification steps are easily deduced, and the method can be used as an early step in the purification process. Active Bromelain enzyme with recovery of $113.54 \%$ and 2.23 purification fold has been extracted from pineapple peel using a combination of 15\% polyethylene glycol (PEG) and 14\% magnesium sulphate. Utilizing a similar method Bromelain was isolated from stem, leaves, and bark of pineapple bromelain using 10.86\% PEG and 36.21\% ammonium sulphate which yielded $66.83 \%$ activity of the product with the purification fold of 11.8. The method shows that increasing the PEG/ salt percentage in the top layer increases the recovery of protein. Parallel to the above study, thermo separation process was carried out in the aqueous medium with the system of polypropylene oxide (PPO)-polyethylene oxide (PEO)-PEO block. The method showed an activity recovery of 79.5\%, and a purification fold of 1.25 suggesting that it is not an effective method compared to the previous study.

Using Ion exchange chromatography highly pure bromelain was obtained. Three times purer bromelain was obtained using cation, exchange resin, diethylaminomethyl (DEAE) based resin, DEAESepharose resin and carboxymethylcellulose resin [16] with the overall enzyme activity recovery of $84.5 \%$ and the purification fold of 10 . Precipitation was used to remove the trace contaminants. Different techniques have been adapted with a difference in the type of ion exchange used and the lysis buffer to get the purified form of bromelain from various parts of the pineapple. Lysis of pineapple stem in 50mM lysine buffer followed by purification using CM Sephadex gave pure bromelain from pineapple stem. Various other conditions successful in purifying bromelain from stem include use of $0.02 \mathrm{M}$ sodium citrate buffer for lysis, $0.2 \mathrm{M}$ potassium phosphate with DEAE cellulose, and $10 \mathrm{mM}$ Tris-HCl buffer. Isolation from fruit was done using Anion (Q-Sepharose) and 0.1M sodium phosphate, $5 \mathrm{~mm}$ EDTA, $5 \mathrm{mM}$ cysteine buffer, Anion (DEAE cellulose) and 0.02M potassium phosphate buffer, Anion exchange resin (Duolite A-2) with $0.05 \mathrm{M}$ potassium phosphate, Cation (Mono Q HR) resin with 20mM Tris- $\mathrm{HCl}$ bromelain, and Ani DEAE cellulose resin with potassium phosphate buffer [24]. SP-Sepharose and a combination of a $20 \mathrm{mM}$ acetate buffer and a $0.1 \mathrm{mM}$ of EDTA were also used for purification of Bromelain from stem.

Precipitation of bromelain from the pineapple stem with $99.5 \%$ alcohol was carried out in a fed-batch system. The entire process is temperature sensitive in order to avoid the loss in the enzyme activity. In order to improvise the yield and activity various methods have been tested, from the fruit. Ammonium sulphate precipitation followed by chromatography yielded 50-70\% of the enzyme by spray dry and $96 \%$ of enzyme by freeze dry with purification fold 2.8. Ethanol concentration from 30-70\% precipitated $98 \%$ of a protein and fold purification of 2.28. Glucose $(10 \% \mathrm{w} / \mathrm{v})$ as a cryoprotectant was added to prevent denaturation of the protein after the lyophilization process. Alternatively, ethanol precipitation (30-70\%) at $4^{\circ} \mathrm{C}$ gave $98 \%$ recovery and a purification fold of 2.07. Precipitation using carrageenan polysaccharide to avoid salts and organic solvents showed recovery of $80-90 \%$ of bromelain from the stem and peel. Reverse micellar extraction followed by precipitation gave 78.90\% recovery and 3.96 purification fold of bromelain from stem. 
By using a system of a sequential batch membrane in which microfiltration with $8 \mu \mathrm{m}$ mineral and followed by ultrafiltration, bromelain was recovered. Post ultrafiltration the sample was subjected to 65\% ammonium sulphate precipitation and ultracentrifugation at $27,000 \mathrm{xg}$ at $2-3^{\circ} \mathrm{C}$. Freeze drying of the final product yielded $98 \%$ of protein. Polyvinyl fluoride microfiltration utilizing 10 $\mathrm{kDa}$ Millipore ultrafiltration unit could recover protein activity of $85 \%$. Purification with a reverse micellar system utilizing cetylammoniumbromide-isooctanehexanol-butanol extraction followed by purification with cellulose acetate ultrafiltration resulted in recovering $95.8 \%$ of enzyme activity with fold purification of 5.9fold.

Bromelain is a protein-digesting enzyme. Though it has protease activity predominantly other activities associated with it include phosphatase, cellulase, peroxidase and glucosidase. Bromelain isolated from stem comprising 212 amino acids exist as a single polypeptide chain with two domains and are stabilized by disulfide, and hydrogen bonds. The molecular mass of bromelain is $24.5 \mathrm{kDa}$, with a pI value of 9.55 and diffusion coefficient of $7.77 \times 10-7 \mathrm{~cm} 2 / \mathrm{s}$. The important feature of stem bromelain is its thermal stability at the temperature range between $40-60{ }^{\circ} \mathrm{C}$ where usually most of the enzymes get denatured. Bromelain isolated from the stem is an endoprotease, which can cleave the peptide bond in the protein molecule. The interaction of bromelain and substrate complex was found to be non-covalent bonding. The enzyme substrate reaction is followed by the acylation and deacylation processes where the enzyme undergoes acylation and produces amine as a first product, which is followed by deacylation process between water and acyl-enzyme to release a free enzyme of carboxylic group. Bromelain is active in the $\mathrm{pH}$ range of 5.5 to 8.0 .

The amino acid sequence analysis of the whole enzyme indicated a frequency of occurrence of valine at the amino terminal region of the protein. At the $\mathrm{N}$-terminus presence of other amino acid residues like alanine, and glycine was observed to be at a frequency of 0.2 and 0.06 residues per molecule of enzyme. The Amino-terminal of bromelain isolated from the fruit also contains alanine, valine, serine, and glucose at a frequency of 0.9, 0.3, 0.2 , and 0.1 residues per molecule respectively. The enzyme isolated from the stem is basic in nature, which is based on observations from an amino acid analysis of the enzyme. The analysis showed the presence of a high amount of basic amino acids like lysine and arginine. In 1967, Murachi verified glycoprotein nature of enzyme is confirmed by the presence of carbohydrate moieties attached covalently to protein. Purification of the bromelain revealed $2.1 \%$ of carbohydrates and hexosamine moiety per molecule. The molecular weight of the enzyme was reported to be 33,000daltons. Overall, various studies show that the bromelain isolated from the stem is a glycoprotein and it's percentage recovery and fold purification is shown in Table 1 . The structure of the enzyme and its overall biochemical properties confirm its pharmacological role.

\begin{tabular}{|c|c|c|c|c|}
\hline Sl. No. & Purification technique & Recovery (\%) & Fold purification & Reference \\
\hline 1 & $\begin{array}{l}\text { Aqueous two- } \\
\text { phase extraction }\end{array}$ & 55.6 & 16.3 & [6] \\
\hline 2 & 15\% PEG and 14\% Magnesium sulphate & 113.54 & 2.23 & {$[10]$} \\
\hline 3 & 10.86\% PEG and 36.21\% Ammonium sulphate & 66.83 & 11.8 & {$[11]$} \\
\hline 4 & PP0-PEO block & 79.5 & 1.25 & {$[10,11]$} \\
\hline 5 & Ammonium sulphate precipitation and chromatography & $50-70$ & 2.8 & [13] \\
\hline 6 & Ammonium sulphate precipitation and Spray drying & 96 & 2.8 & [13] \\
\hline 7 & Ethanol concentration of precipitated protein & 98 & 2.28 & {$[27]$} \\
\hline 8 & Ethanol precipitation at $4{ }^{\circ} \mathrm{C}$ & 98 & 2.07 & {$[28]$} \\
\hline 9 & Reverse micellar extraction followed by precipitation & 78.9 & 3.96 & [30] \\
\hline 10 & $\begin{array}{c}\text { Reverse micellar extraction } \\
\text { followed by cellulose acetate ultrafiltration }\end{array}$ & 95.8 & 5.9 & [32] \\
\hline
\end{tabular}

\section{Industrial Application of Bromelain}

2.1. Baking Industry: In the baking industry, bromelain is used for improving dough quality and rise. Gluten is a major component of wheat. As Gluten is insoluble in water, it forms a lattice-like structure. Bromelain removes gluten from wheat, ensuring proper dough formation. Bromelain is also used to produce flour of hypoallergic nature.
2.2. Tenderization: Bromelain helps in the hydrolysis of myofibril proteins in meat, chicken, and oyster. The protease activity of the enzyme bromelain breaks collagen fiber leading to meat tenderization process. The sulfhydryl group of cysteine in the protease is responsible for the proteolytic action of collagen fiber, leading to the process of tenderization that makes the meat more palatable. 
2.3. Fish protein hydrolysis: The Bromelain enzyme produces fish hydrolysate by hydrolyzing the proteins in fish. The hydrolysate is widely used as a nutritional supplement and an important ingredient in some pharmaceutical industries. The study recorded that bromelain was responsible for a high index of emulsion stability and foaming capacity.

2.4. Anti-browning agent: Bromelain is used in preventing undesirable changes due to phenol oxidation that affects the flavor and the nutritional quality of fruits. Phenolic oxidation produces a brown color pigment and is primarily responsible for causing undesirable changes. A sliced apple ring when treated with bromelain showed a significant reduction in the browning process and potentially increasing the fruit shelf- life.

2.5. Alcohol stability: Bromelain is used for enhancing the stability of the protein and preventing haziness in beer. Bromelain enhances the stability of the white-wine protein. The bromelain isolated from the stem was active at the minimum $\mathrm{pH}$ value of wine and showed an increase in the Ka value by $42 \%$, acting as an alcoholic-acid buffer and thereby acting as an excellent protease enzyme in the production and stabilization of wine.

2.6. Animal feed: Bromelain is used for the estimation of protein degradation in the feed of the ruminant. In weanling pigs, $0.2 \%$ of bromelain was used as a dietary supplement, improving the growth rate of pigs, with reduced E.coli contamination and $\mathrm{NH} 3$ gas in the feces.

2.7. Textile industry: The conventional method of cocoon cooking and treating it with a strongly alkaline solution reduces the quality of the silk thread. Alternatively, the use of pineapple juice and sodium carbonate reduces the cooking time of a cocoon for its softening. Pineapple juice is found to be effective in removing impurities from wool and silk fibers and enhancing the production scale. It also improves the properties of the dyeing of fibers.

2.8. Tooth whitening: Bromelain helps in removing stains, plaques, and food debris from the teeth. Certain food and beverages impart extrinsic coloration to the teeth. The dentifrice bromelain, by its proteolytic activity, degrades the accumulated protein on the tooth and gives higher lightening.

2.9. Cosmetic industry: Bromelain can be used to treat acne and wrinkles, and to reduce swelling, bruising and drying of the skin. Bromelain proteolyses the protein of the upper layer of skin cells, paving a way for the replacement of young cells. The study also reports that the application of bromelain on the skin reduces the bruises caused during cosmetic surgeries.

\section{Application In Healthcare}

3.1. Antimicrobial Activity: Beverages and citric juices are acidic and undergo deterioration caused by sporeforming bacteria Alicyclobacillus sps. Studies have shown that papain and bromelain, obtained from papaya and pineapple are the main proteolytic enzymes that are used as preservatives in the pharmaceutical and food industry. The minimum inhibition concentration, minimum bactericidal concentration, the deathtime logarithmic curve of a bacteria, and enzymatic mechanism against bacteria revealed that bromelain is effective in controlling the deterioration of the products due to Alicyclobacillus sps. The activity of this enzyme as an antibacterial agent is due to other activities associated with an enzyme such as amidase and esterase.

Bromelain protects animals from infections caused by E.coli and Vibrio cholera, by acting on signaling cascades like a calcium-dependent pathway. It is effective on adenosine 3'-5cylic monophosphate, and guanosine $3^{\prime}-5^{\prime}$ cylic monophosphate pathways. The K88+ETEC is an enterotoxigenic strain of E.coli that is responsible for diarrhea in piglets. Treatment with bromelain showed proteolysis of this adhesion molecule and thereby inhibiting the attachment of the strain to the receptor. Bromelain which is a cysteine protease is active against gastrointestinal nematode Heligmosomoides polygyrus. Bromelain has anti-helminthic activity against Trichuris muris, which is a rodent intestinal nematode.

3.2. Anticancer Activity: Bromelain was tested as an oral drug in the year 1972. Patients with the breast and ovarian cancer were treated with $600 \mathrm{mg}$ of bromelain daily for about 6 months. The study observed that there was a considerable decrease in cancer mass and metastasis rate post treatment. The studies showed that combination therapy of the $1000 \mathrm{mg}$ bromelain with a chemotherapeutic agent such as 5-FU and vincristine on a daily basis gave a significant regression in the tumor growth. In-vivo analysis of the anti-tumoral and antileukemic activity of bromelain on various cancer induced in B6D2/F1 mice by intraperitoneal injection of various cell lines such as S-37, P-388, LLC, EAT, ADC-755, and MB-F10 showed an increase in survival time, except for MB-F10 which is a melanoma cell line. The Murine model is routinely used for the evaluation of antitumor and antimetastatic activity of Bromelain. The cell line used for the study of the anti-cancer activity of bromelain is Syngenic sarcoma (L-1).

The L1 cells were incubated with bromelain and injected into murine mice (BALB/C) intravenously or subcutaneously and compared with L-1 cells injected into mice that were later treated with bromelain. In the first case, the experiment proved a reduction in tumor growth and metastasis rate. In the second case, the experiment showed a reduction in tumor growth, but the colonization of the cancer cells was not reduced significantly. Bromelain and $\mathrm{N}$-acetylcysteine were evaluated individually and in a synergic combination for their growth-inhibitory action against gastrointestinal human carcinoma cell lines using the sulforhodamine B assay method. The cell lines selected for the study are KATO-III, HT-295F12, HT29-5M21, LS174T, and MKN45. The results revealed that the growth was significantly controlled and the cytotoxic effect was highly regulated by a combination of Bromelain and $\mathrm{N}$-acetylcysteine [58]. 
C57B1/6 laboratory mice chow was used to study the anti-metastatic activity of Bromelain. Lewis lung cancer cells were injected subcutaneously for the development of lung cancer, and treatment with Bromelain resulted in a reduction in the lung metastatic rate.

The formulated bromelain nanoparticles were $130.4 \pm 8.81$ $\mathrm{nm}$ in size and showed sustainable release of the drug, resulting in antitumor activity in the second-stage skin cancer model in mice, with a reduction in tumorigenesis, the percentage rate of mortality, and reduced tumor volume. The skin of the mouse, when pretreated with bromelain and injected with cancer cells, showed a reduction in the CNT (cumulative number tumor). The study also showed a reduction in the volume of the tumor. Bromelain targets the signal transduction pathway in the cell. The enzyme targets the proteins that are involved in the cell cycle arrest and cell death. The study showed that bromelain upregulated genes are involved in the apoptotic pathway. p53 and BAX are upregulated which results in activation of caspases 3 and 9, which subsequent decrease in the expression of Bcl-2 along with inactivation NF- $\mathrm{KB}$ and inhibition of Cox-2. Bromelain curtailed some proteins that are associated with extracellular signaling pathways like MAPK, p38, ERK1/2, and Akt activity. Studies were done in the A431 epidermoid carcinoma and the A375 melanoma showed bromelain inhibiting the process of proliferation.

The Akt regulated kappa B nuclear factor activation was inhibited through the suppression of phosphorylation of "inhibitory-kappa B $\alpha$ ". This resulted in inhibition of the activity of cyclooxygenase 2 which results in the suppression of inflammatory signals. The druginduced the arrest of the cell cycle at the G2/M phase by depleting the level of glutathione. Bromelain inhibits the translocation of nuclear factor kappa B thus causing induction of apoptosis. In the invivo lung metastasis models bromelain showed anti-metastatic activity in its active and inactive state (anti-coagulant and proteolytic activity) in a dose-dependent manner. Treatment with Bromelain results in the Up-regulation of p53 and Bax with subsequent activation of caspases 3 and 9 in stage two skin cancer models of the mouse. Bromelain inhibits $\mathrm{Bcl}-2$ which in turn affects Cox-2 activity by inactivating NF-kB (nuclear factor-kappa B). Thus, the protease affects the extracellular signaling pathway by inhibiting MAPK and Akt/protein kinase B signaling pathways which demonstrates the potent anti-tumorigenic activity by Bromelain. Gastric carcinoma cell lines KATO-III and MKN45 and colon adeno carcinoma cell lines HT295M21, HT29-5F12 when treated with bromelain show reduction in the cell proliferation rate and enhanced apoptosis. Bromelain acts by blocking the Akt pathway and also attenuating the oncoprotein $\mathrm{Bcl} 2$ and MUC1 in these cell lines.

Treatment of breast cancer and pancreatic cancer with adjuvant bromelain along with 5-FU and cisplatin showed a reduction in levels of MUC1 which serves as biomarker protein for these cancers. Intraperitoneal injection of bromelain and fastuosain in C57B1/6 the mice model, induced with B16F10-Nex2 melanoma cells showed reduced expression of CD44.Treatment of glioma cells with Bromelain suggests that the drug significantly reduces the adhesion property, the invasion, and migration of glioma cells, without affecting its viability. The study demonstrated that there is a reduction in the CD44 protein expression even though the RNA expression level of this protein was unaltered post treatment. A detailed study of signaling pathways affected by Bromelain showed that there was a suppression of the CRE-mediated signaling pathway. Thus, bromelain has a major role to play at the molecular level. The study revealed the effect of bromelain on advanced colon rectal cancer in zebra fish and in mouse model. The protein induced apoptosis and inhibited CRC cell progression.

Angiogenesis and Metastasis are the major reasons for high mortality rates in different forms of cancer. As the cancer cells enter into the circulatory system, they spread the growth of tumor in a different part of the body by stimulating new blood vessels for its growth and progression. For cancer cells to metastasize mechanisms such as angiogenesis, adhesion, invasion and proliferation of the cell are extremely important. The studies have proved that bromelain interferes in these disease-progressing mechanisms and can control the spread of tumor. The migrating cancer cells attach to the receptor protein molecule at different site in each tissue. These proteins play an important role in adhesion and invasion. Bromelain inhibits various such cell-adhesion proteins. Suppression of (MMP)-9, a matrix metalloprotein, by bromelain prevents the cancer cell invasion. Bromelain inactivates AP-1 protein and inhibits the signaling pathway of NF- $\mathrm{KB}$.

Studies have shown that tumor cells and platelets are related and mutually associate with the progression of malignancies. Cancer cells activate the production of platelets, which in turn leads to angiogenesis. The main property of a tumor cell is that it aggregates with the platelets as a whole and evades the immune response in the body. Bromelain inhibits this aggregation when administered orally into the system. Angiogenesis is highly regulated by signaling molecules and proangiogenic genes. Bromelain has been studied as an anti-angiogenic molecule on different types of cancerous cells. The various factors like COX-2, MMP-9, AP-1, NF$\kappa \mathrm{B}$, VEGF and angiopoetin-1, 2 shown in Figure 2 are regulated by bromelain. In the mouse model, bromelain showed a reduction in the activity of a tissue remodeling enzyme MMP-9, which is essential for the formation of new blood vessels. In hepatocellular carcinoma, the study revealed the effective reduction of the COX-2 and VEGF in the cells treated with bromelain.

3.3. Immunological Activity: Bromelain showed effects in the patient with encephalomyelitis. It influenced the proliferation of PBMC. Bromelain exhibited an improved increase in the cytokines, Il-6, GM-CSF, TNF- $\alpha$, and IFN- $\gamma$. The increase of IFN $\gamma$ produces an increasing amount of CD4 -T cells, thereby stimulating innate immunity and adaptive immunity. The lymphocytes 
treated with bromelain showed reduced cell surface staining molecules like CD62-L and CD44. There was no effect of treatment on the surface expression of CD56, CD16, and CD49-d. $\beta 2$ integrins and the CD11 a-c expression was slightly elevated in the treated lymphocytes. The production of TNF- $\alpha$, IL-1 $\beta$, and IL- 6 based on the dose and time of exposure to the treatment of bromelain showed increased IFN- $\alpha$ and IFN- $\gamma$ along with an increase in the production of TNF- $\alpha$ because of the tryptic activity of bromelain. Bromelain removes CD44 T-cells from lymphocytes, thereby affecting the T-cell activation which was tested on PBL (peripheral blood lymphocytes) and HUVEC (Human umbilical vein endothelial cells) which showed reduced expression of CD44. F9 fragment of Bromelain showed a high rate of inhibition on the expression of CD44. The active CD4+ T cell shows the expression of CD25 on its surface, which forms an insoluble fraction that is the main target for treating immunological challenges. Treatment with bromelain reduces the expression of CD25 in a dosedependent manner, suggesting its proteolytic effect on CD25.

Figure 2: The schematic highlights of the up-regulation and down-regulation of major transcription factors involved in the progression of cancer that are controlled by Bromelain.

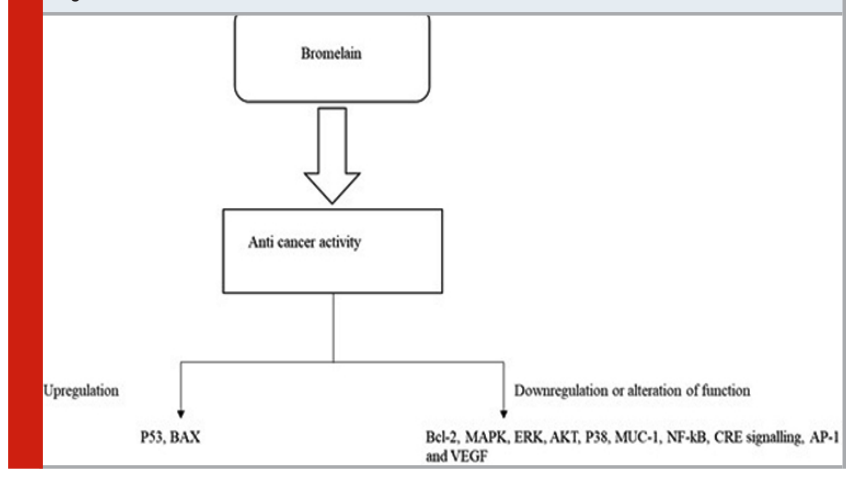

3.4. Anti-Inflammatory: Bromelain decreases the expression levels of mRNA coding cytokines, which are pro-inflammatory markers in human leukocytes under in-vitro condition. The effect of bromelain on cytokines in IBD (Inflammatory bowel disease) patients showed a decrease in the level of G-CSF, IL-6, IL-1 $\beta$, IFN- $\gamma$, MIP-1 $\beta$ and TNF, making it a potent drug for treating inflammatory bowel diseases. The IL-10 deficient murine model with IBD when treated orally with bromelain showed a reduction in the colonic inflammation with less damage to tissue. An inflammatory mediator such as interleukin 1 $\beta$, IL- 6 and tumor necrosis factor $\alpha$ production was increased in a dose-dependent pattern when PBMNC (peripheral blood mononuclear cells) were treated with a proteolytic enzyme like bromelain.

4. Other Clinical Applications: Bromelain being a proteolytic enzyme plays an important role in preventing IgE mediated allergic reactions such as the immediate, delayed or late phase hypersensitivity symptoms which are mainly associated with the respiratory tract. Bromelain induced changes in CD62P make it a potent platelet inhibitor. Treating with the $2.5 \mathrm{mg}$ of bromelain reduces the ADP induced platelet aggregation and shows a significant reduction in TRAP- 6 induced plate aggregation. Incubating with $2.5 \mathrm{mg} / \mathrm{ml}, 5 \mathrm{mg} / \mathrm{ml}$ of bromelain showed a drastic reduction in TRAP-6 induced aggregation of platelets. Under in-vitro conditions, bromelain showed an effect on plasminogen. Plasminogen was activated to produce plasmin known for its activity to cleave fibrin. Bromelain, a protease enzyme, is efficient in reducing the human platelet's aggregation process. Pre-incubation of platelets with bromelain showed inhibition of the thrombus-induced platelet aggregation process in a time-dependent manner. Bromelain showed an effect in reducing the level of TGF-beta (Transforming Growth Factor-beta) which is overexpressed in the blood during disease conditions.

The protein trigger Akt dependent pathway, a survival pathway that can be used as a cardioprotective drug against I/R injury. Bromelain was used as a debriding agent in the formulation of a gel known as DGB (Debriding gel dressing) for treating intense burns. Immunomodulation activity in blood samples from CVID (common variable immune deficiency) and XLA (X-linked agammaglobulinemia) patients suffering with infection from Candida albicans showed enhanced phagocytic activity upon treatment with Bromelain. Skin disease caused by Pityriasis lichenoides chronica is completely cured by bromelain. Bromelain influences the penetrability of the antibiotic amoxicillin and its increase in blood and urine. It along with trypsin and rutin as a combination is used as an adjuvant with antibiotics to treat children suffering from sepsis. Enzymes purified from Aspergillus niger and bromelain provides as a feed supplement through tube feeding in elderly nursing people showed an increase in the protein uptake. It also acts as a digestive enzyme and can be treated in intestinal disorders such as pancreatectomy.

Intraduodenal or by the parenteral administration of bromelain into traumatized rats with hind limb edema showed stability in the protein molecule on absorption in the gut region and considerable reduction in edema determined volumetrically. Studies on bromelain showed a reduction in the activity of fibrinolysis, inhibiting the formation of thrombus and reducing the plate aggregation. Analogous studies on coronary heart disease revealed that there was reoccurrence of angina attacks when the bromelain treatment was discontinued for almost 2 months. An oral administration of bromelain on hypersensitive people showed that thrombophlebitis can be treated. In case of ischemic experiments, myocardial injuries can be reduced by treating with bromelain, which restores the functional status of the heart. The study found that bromelain also resulted in the increase in the blood flow in aorta, reducing the apoptotic process and reducing the damage in the endothelial cell in the case of hepatic ischemic patients.

In patients with knee osteoarthritis, the administration of bromelain showed a significant decrease in stiffness 
and pain in the joints. Furthermore, bromelain also treats patients with inflammatory bowel disease by exerting a negative control on the expression of the colony stimulating factor and INF- $\gamma$ which are proinflammatory molecules $[107,108]$. Studies have shown that bromelain up to $12 \mathrm{~g} / \mathrm{d}$ can be consumed with no side effects. On absorption, bromelain is highly stable in the gastrointestinal tract with an absorption rate of 40\% as claimed by researchers. In the blood, the proteolytic nature of the enzyme is retained and is linked with antiproteases. It is claimed that $3.66 \mathrm{mg} / \mathrm{ml}$ and $2.44 \mathrm{mg} /$ $\mathrm{ml}$ of bromelain after four hours of administration is maintained stable in artificial environment with stomach juices and blood respectively.

Present pandemic situation in the world due to COVID19 (Corona virus disease-19) by SARS-CoV-2 (severe acute respiratory syndrome coronavirus-2). In this study, authors demonstrated that bromelain reduced the expression of angiotensin-converting enzyme- 2 (ACE-2) and Transmembrane serine protease-2 (TMPRSS2) which are responsible for viral pathogenesis. Hence, the researcher suggests that bromelain can be used to cure COVID-19 (this research is preprint and is not peer reviewed till date). In line with the above study here, the authors reported that Bromelain in combination with Curcumin can control COVID-19 pathogenesis due to its anti-inflammatory property which might significantly block the transcription factors and down-regulates the pro-inflammatory markers. Hence bromelain has a wide spectrum of activities as shown in Figure 3 and plays a vital role in treating various kinds of clinical complications and is an effective natural phytocompound.

Figure 3: Schematic highlights of the major applications of Bromelain in different sectors of Industry and Healthcare.

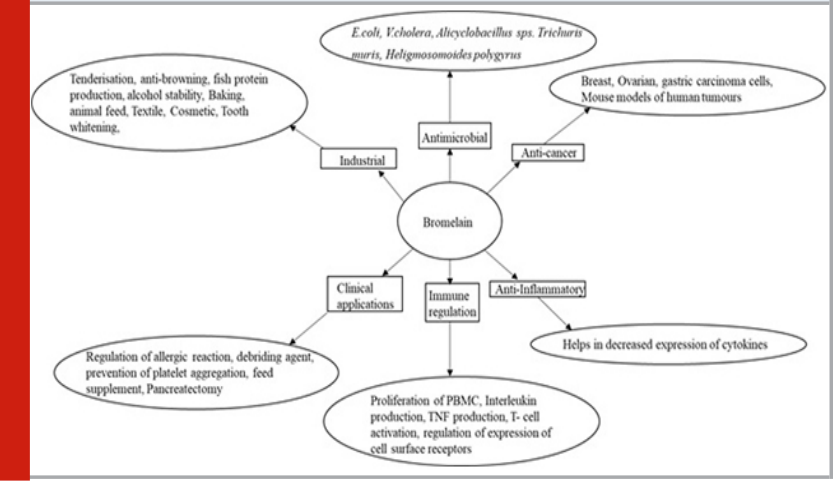

CONCLUSION

Bromelain which is a protease enzyme plays a major role in various sectors of health care and industries. The purification strategies revealed improvisation in the techniques for good percentage recovery with better fold purification. It is used as a food supplement to increase protein uptake in elderly patients. In cancerous tissue, bromelain down-regulates the molecules like $\mathrm{CD} 44$ which are responsible for the invasive nature of metastasis cancer. The protein kinase, a potent anticancer drug significantly blocks the Akt/ PKB signaling pathway, inhibits the expression of Cox-2, masks Bcl2 and alters the ratio of $\mathrm{Bcl} 2 / \mathrm{Bax}$ involved in cancer cells and induces the expression of cancer repressor protein p53, thus preventing the growth of cancer cells. In antiinflammatory reactions, it reduces platelet aggregation and cytokines production. Despite its promising action as an anti-cancer drug, there is a lacuna in understanding the effect of bromelain on the major transcription factors and it signaling pathways that are involved in the progression of normal cell to metastatic condition. Hence, the present review article suggests the need for scientific emphasis on the same for the complete insight of bromelain as a promising anti-cancer agent so that the drug targeted therapy will be the scope of future research. The structural, functional properties and bioavailability of bromelain make the molecule a pharmacological active drug. Finally, bromelain is a potent drug that can be explored for various health care applications.

Conflict of Interest: The authors declare that there are no conflicts of interest.

\section{REFERENCES}

Amid A, Ismail NA, Yusof F, Salleh HM. Expression, purification, and characterization of a recombinant stem bromelain. Process Biochem. 2011; 46(12): 22322239.

Amini A, Masoumi-Moghaddam S, Ehteda A. Bromelain and $\mathrm{N}$-acetylcysteine inhibit proliferation and survival of gastrointestinal cancer cells in vitro: significance of combination therapy. J ExpClin Cancer Res. 2014; 33: 92-97.

Anjos dos MM. Antibacterial activity of papain and bromelain on Alicyclobacillus sps. International Journal of Food Microbiology. 2016; 216(4):121-126.

Arshad ZIM, Amid A, Yusof F, Jaswir I, Ahmad K, Loke SP. Bromelain: an overview of industrial application and purification strategies. Appl. Microbiol Biotechnol. 2014; 98: 7283-7297.

Babu BR, Rastogi NK, Raghava Rao KSMS. Liquid-liquid extraction of bromelain and polyphenol oxidase using aqueous two-phase system. Chem. Eng. Process. 2008; 47(1): 83-89.

Báez R, Lopes M, Salas C, Hernández M. In Vivo Antitumoral Activity of Stem Pineapple (Ananascomosus) Bromelain. Planta Medica. 2007; 73(13): 1377-1383.

Bahde R, Palmes D, Minin E, Stratmann U, Diller R, Haier J Spiegel HU. Bromelain ameliorates hepatic microcirculation after warm ischemia. J Surg Res. 2007; 139: 88-96.

Bala M, Ismail NA, Mel M, Jami MS, Mohd Salleh H, Amid A. Kinetic studies on recombinant stem bromelain. Adv. Enzyme Res. 2013; 1(3): 52-60.

Balakrishnan V, Hareendran A, Nair CS. Double-blind cross over trial of an enzyme preparation in pancreatic steat־orrhoea. J Assoc Physicians India. 1981; 29: 207 - 
209.

Barth H, Guseo A, Klein R. In vitro study on the immunological effect of bromelain and trypsin on mononuclear cells from humans. Eur J Med Res. 2005; 10(8): 325-331.

Batkin S, Taussig SJ, Szekerezes J. Antimetastatic effect of bromelain with or without its proteolytic and anticoagulant activity. J Cancer Res ClinOncol. 1988; 114: 507.

Benucci I, Liburdi K, Garzillo AMV, Esti M. Bromelain from pineapple stem in alcoholic-acidic buffers for wine application. Food Chem. 2011; 124(4): 1349-1353.

Bhatnagar P, Pant AB, Shukla Y, Chaudhari B, Kumar P, Gupta KC. Bromelain nanoparticles protect against 7,12dimethylbenz[a]anthracene induced skin carcinogenesis in mouse model. European Journal of Pharmaceutics and Biopharmaceutics. 2015; 91: 35-46.

Bhui K, Prasad S, George J, Shukla Y. Bromelain inhibits COX-2 expression by blocking the activation of MAPK regulated NF-kappa B against skin tumor-initiation triggering mitochondrial death pathway. Cancer Letters. 2009; 282:167-176.

Bhui K, Tyagi S, Srivastava AK, Singh M, Roy P, Singh R, Shukla Y. Bromelain inhibits nuclear factor kappa-B translocation, driving human epidermoid carcinoma A431 and melanoma A375 cells through G2/M arrest to apoptosis. Molecular Carcinogenesis. 2011; 51(3): 231-243.

Brakebusch M, Wintergerst U, Petropoulou T, Notheis G, Husfeld L, Belohradsky BH, Adam D. Bromelain is an accelerator of phagocytosis, respiratory burst and Killing of Candida albicans by human granulocytes and monocytes. Eur J Med Res. 2001; 6(5): 193-200.

Bresolin IRAP, Bresolin ITL, Silveira E, Tambourgi EB, Mazzola PG. Isolation and Purification of Bromelain from Waste Peel of Pineapple for Therapeutic Application. Braz. Arch. Biol. Technol. 2013; 56(6): 971979.

Bruno M, Trejo S, Avilés X, Caffini N, López L. Isolation and characterization of hieronymain II, another peptidase isolated from fruits of Bromelia hieronymi Mez (Bromeliaceae). Protein J. 2006; 25(3): 224-231. Campos DA, Valetti NW, Oliveira A, Pastrana-Castro LM, Teixeira JA, Pintado MM, Picó G. Platform design for extraction and isolation of Bromelain: Complex formation and precipitation with carrageenan. Process Biochem. 2017; 54: 156-161.

Chakravarthy PK, Acharya S. Efficacy of extrinsic stain removal by novel dentifrice containing papain and bromelain extracts. J Young Pharm. 2012; 4(4): 245-249.

Chandler DS, Mynott T L. Bromelain protects piglets from diarrhoea caused by oral challenge with K88 positive enterotoxigenic Escherichia coli. Gut. 1998; 43(2): 196-202.

Chang TC, Wei PL, Makondi PT, Chen WT, Huang CY, Chang YJ. Bromelain inhibits the ability of colorectal cancer cells to proliferate via activation of ROS production and autophagy. PLoS One. 2019; 14(1): 274.

Chaurasiya RS, Hebbar HU. Extraction of bromelain from pineapple core and purification by RME and precipitation methods. Sep. Purif. Technol. 2013; 111: 90-97.

Coelho DF, Silveira E, Pessoa Junior A, Tambourgi EB. Bromelain purification through unconventional aqueous two-phase system (PEG/ammonium sulphate). Bioprocess Biosyst Eng. 2013; 36(2): 185- 192.

Costa HB, Fernandes PMB, Romão W, Ventura JA. A new procedure based on column chromatography to purify bromelain by ion exchange plus gel filtration chromatographies. Ind. Crops Prod. 2014; 59: 163168.

Desser L, Holomanova D, Zavadova E, Pavelka K, Mohr T, Herbacek I. Oral therapy with proteolytic enzymes decreases excessive TGF- $\bigotimes$ levels in human blood. Cancer Chemotherapy and Pharmacology. 2001; 47: 10-15.

Desser L, Rehberger A, Kokron E. Cytokine synthesis in human peripheral blood mononuclear cells after oral administration of polyenzyme preparations. Oncology. 1993; 50: 403-407.

Desser L, Rehberger A. Induction of tumor necrosis factor in human peripheral-blood mononuclear cells by proteolytic enzymes. Oncology. 1990; 47:475-477. Devakate RV, Patil VV, Waje SS, Thorat BN. Purification and drying of bromelain. Sep. Purif. Technol. 2009; 64(3):259-264

Doko MB, Bassani V, Casadebaig J, Cavailles L, Jacob M. Preparation of proteolytic enzyme extracts from Ananas comosus L., Merr.fruit juice using semipermeable membrane, ammonium sulphate extraction, centrifugation and freeze-drying processes. Int. J. Pharm. 1991; 76(3): 199-206.

Doreen glaser ,Thomas Hilberg. The influence of Bromelain on platelet count and platelet activity in vitro. Platelets. 2006; 17(1): 37-41.

Elavarasan K, Naveen Kumar V, Shamasundar BA. Antioxidant and functional properties of fish protein hydrolysates from fresh water carp (Catlacatla) as influenced by the nature of enzyme. J Food Process Preserv. 2013; 38(3): 1207-1214.

Ferreira JF, Sbruzzi D, Barros KVG, Machado IS, Tambourgi EB. Purificação da enzima bromelina presente no curauá (Ananas erectifolius L.B. SMITH) variedade roxa, por sistema bifásico aquoso PEG 4000/ fosfato de potássio. Rev. Bras. Prod. Agro ind. 2011; 13: 197-202.

Gailhofer G, Wilders-Truschnig M, Smolle J, Ludvan M. Asthma caused by bromelain: an occupational allergy. Clin Allergy. 1988; 18: 445-450.

Garbin F, Harrach T, Eckert K, Maurer HR. Bromelain proteinase-f9 augments human lymphocyte-mediated growth inhibition of various tumor cells in vitro. Int $\mathrm{J}$ 
Oncol. 1994; 5: 197-203.

Gautam SS, Mishra SK, Dash V, Goyal AK, Rath G. Comparative study of extraction, purification and estimation of bromelain from stem and fruit of pineapple plant. Thai J. Pharm. Sci. 2010; 34: 67-76. Gerard G. Anti-cancer therapy with bromelain. Agress. 1972; 3: 261-274.

Glade MJ, Kendra D, Kaminski MV. Improvement in protein utilization in nursing-home patients on tube feeding supplemented with an enzyme product derived from Aspergillus nigerand bromelain. Nutrition. 2001; 17: 348-350.

Glaser D, Hilberg T. The influence of bromelain on platelet count and platelet activity in vitro. Platelets. 2006; 17(1): 37-41.

Guimaraes-Ferreira CA, Rodrigues EG, Mortara RA, Cabral H, Serrano FA, Ribeiro-dos-Santos R, Travassos LR. Antitumor Effects In Vitro and In Vivo and Mechanisms of Protection against Melanoma B16F10Nex2 Cells By Fastuosain, a Cysteine Proteinase from Bromelia fastuosa. Neoplasia. 2007; 9(9): 723-733. Gutfreund AE, Taussig SJ Morris AK. Effect of oral bromelain on blood pressure and heart rate of hypertensive patients. Hawaii Med J. 1978; 37: 143146.

Hage DS, Anguizola JA, Bi C, Li R, Matsuda R, Papastavros E, Pfaunmiller E, Vargas J, Zheng X. Pharmaceutical and biomedical applications of affinity chromatography: recent trends and developments. J Pharm Biomed Anal. 2012; 93-105.

Hale L, Greer P, Trinh C, Gottfried M. Treatment with oral bromelain decreases colonic inflammation in the IL-10-deficient murine model of inflammatory bowel disease. Clinical Immunology. 2005; 116(2): 135-142. Hale LP, Greer PK, Trinh CT, James CL. Proteinase activity and stability of natural bromelain preparations. Int Immunopharmacol. 2005; 5(4): 783-793.

Harrach T, Eckert K, Maurer HR, Machleidt I, Machleidt W, Nuck R. Isolation and characterization of two forms of an acidic bromelain stem proteinase. J Protein Chem. 1998; 17(4): 351-361.

Harrach T, Eckert K, Schulze-Forster K, Nuck R, Grunow $\mathrm{D}$, Maurer HR. Isolation and partial characterization of basic proteinases from stem bromelain. J Protein Chem. 1995; 14(1):41-52.

Hebbar UH, Sumana B, Hemavathi AB. Separation and Purification of Bromelain by Reverse Micellar Extraction Coupled Ultrafiltration and Comparative Studies with Other Methods. Food Bioprocess Technol. 2012; 5: 10101018.

Iffah Zatul, Amid Azura ,Yusof Faridah, Jaswir Irwandi Ahmad, Kausar Pau Loke, Show. Bromelain: An overview of industrial application and purification strategies. Applied microbiology and biotechnology. 2014; 98 (17):7283-7297.

Janhvi Manohar, Gayathri R, Vishnupriya V. Tenderisation of Meat Using Bromelain from Pineapple Extract. Int. J.
Pharm. Sci. Rev. Res. 2016; 39(1): 81-85.

Josef Beuth, Jan Matthais Braun. Modulation of Murine Tumor Growth and Colonization by Bromelaine, an Extract of the Pineapple Plant (AnanasComosum L.). in vivo. 2005; 19:483-486.

Juhasz B, Thirunavukkarasu M, Pant R, Zhan L, Penumathsa SV, Secor ER Jr, Srivastava S, Raychaudhuri U, Menon VP, Otani H, Thrall RS, Maulik N. Bromelain induces cardioprotection against ischemia-reperfusion injury through Akt/FOXO pathway in rat myocardium. Am J Physiol Heart CircPhysiol. 2008; 294: 13651370.

Kalra N, Bhui K, Roy P, Srivastava S, George J, Prasad $S$, Shukla Y. Regulation of p53, nuclear factor $\otimes B$ and cyclooxygenase-2 expression by bromelain through targeting mitogen-activated protein kinase pathway in mouse skin. Toxicology and Applied Pharmacology. 2008; 226(1): 30-37.

Kalyana P, Shashidhar A, Meghashyam B, SreeVidya $\mathrm{KR}$, Sweta S.Stain removal efficacy of a novel dentifrice containing papain and bromelain extracts-an in vitro study. Int J Dent Hyg. 2011; 9(3): 229-233.

Karlsen M, Hovden A0, Vogelsang P, Tysnes BB Appel S. Bromelain treatment leads to maturation of monocytederived dendritic cells but cannot replace PGE2 in

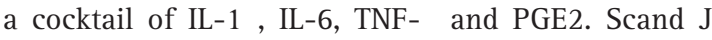
Immunol. 2011; 74: 135-143.

Ketnawa S, Rawdkuen S, Chaiwut P. Two phase partitioning and collagen hydrolysis of bromelain from pineapple peel Nang Lae cultivar. Biochem Eng J. 2010; 52(2-3) : 205-211.

Kleef R, Delohery TM, Bovbjerg DH. Selective Modulation of Cell Adhesion Molecules on Lymphocytes by Bromelain Protease 5. Pathobiology. 1996; 64(6): 339-346.

Koh J, Kang S-M, Kim S-J, Cha M-K, Kwon Y-J. Effect of pineapple protease on the characteristics of protein fibers. Fibers Polym. 2006; 7(2): 180-185.

Kong X, Zhou H, Qian H. Enzymatic hydrolysis of wheat gluten by proteases and properties of the resulting hydrolysates. Food Chem. 2007; 102(3): 759-763.

Levy LL, Emer JJ. Complications of minimally invasive cosmetic procedures: prevention and management. J CutanAesthetSurg. 2012; 5(2):121-132.

Lopes FLG, Severo Júnior JB, Souza RRD, Ehrhardt DD, Santana JCC, Tambourgi EB. Concentration by membrane separation processes of a medicinal product obtained from pineapple pulp. Braz. Arch. Biol. Technol. 2009; 52(2): 457-464.

Lozano-De-Gonzalez PG, Barrett DM, Wrolstad RE, Durst RW. Enzymatic browning inhibited in fresh and dried apple rings by pineapple juice. J Food Sci. 1993; 58(2): 399-404.

Luerti M,Vignali ML. Influence of bromelain on penetration of antibiotics in uterus, salpinx and ovary. Drugs ExpClin Res. 1978; 4: 45-48.

Manosroi A, Chankhampan C, Manosroi W, Manosroi 
J. Toxicity reduction and MMP-2 stimulation of papain and bromelain loaded in elastic niosomes. J Biomed Nanotechnol. 2012; 8: 720-729.

Martins BC, Rescolino R, Coelho DF, Zancheta B, Tambourgi EB, Silveira E. Characterization of bromelain from Ananas Comosus agroindustrial residues purified by ethanol factional precipitation. Chem. Eng. Trans. 2014; 37: 781-786.

Massimiliano R, Pietro R, Paolo S, Sara P, Michele F. Role of bromelain in the treatment of patients with pityriasislichenoideschronica. J Dermatolog Treat. 2007; 18: 219-222.

Maurer HR, Eckert K, Grabowska E, Eschmann K. Use of bromelain proteases for inhibiting blood coagulation. 2000; Patent WO PCT/EP 98/04406.

Morris D, Ehteda Masoumi Moghaddam S, Akhter Pillai. Cytotoxic effects of bromelain in human gastrointestinal carcinoma cell lines (MKN45, KATO-III, HT29-5F12, and HT29-5M21). OncoTargets and Therapy. 2013; 6: 403-409.

Munzig E, Eckert K, Harrach T. Bromelain protease F9 reduces the CD44 mediated adhesion of human peripheral blood lymphocytes to human umbilical vein endothelial cells. FEBS Lett. 1995; 351: 215-218.

Murachi T, Neurath H .Fractionation and specificity studies on stem bromelain. J Biol Chem. 1960; 235(1): 99-107.

Murachi T, Suzuki A, Takahashi N. Evidence for glycoprotein nature of stem bromelain. Isolation of a glycopeptide. Biochem. 1967; 6(12): 3730-3736.

Murachi T. Amino acid composition of stem bromelain. Biochem 1964; 3(7), 932-934.

Mynott T, Guandalini S, Raimondi F, Fasano A. Bromelain prevents secretion caused by Vibrio cholerae and Escherichia coli enterotoxins in rabbit ileum in vitro. Gastroenterology. 1997; 113(1): 175-184.

Nieper HA. A program for the treatment of cancer. Krebs. 1974; 6: 124-127.

Nieper HA. A program for the treatment of cancer. Krebs. 1974; 6:124-127.

Nieper HA. Decrease of the incidence of coronary heart infarct by Mg- and K-orotate and bromelain. Acta Med Empirica. 1977; 12: 614-618.

Nieper HA. Effect of bromelain on coronary heart disease and angina pectoris. Acta Med Empirica. 1978; 5: 274278.

Nor MZM, Ramchandran L, Duke M, Vasiljevic T. Characteristic properties of crude pineapple waste extract for bromelain purification by membrane processing. Food Bioprod. Process. 2015; 52: 71037112.

Oltersdorf T, Elmore SW, Shoemaker AR, Armstrong RC, Augeri DJ, Belli BA, Bruncko M, Deckwerth TL, Dinges J, Hajduk PJ. An inhibitor of Bcl-2 family proteins induces regression of solid tumours. Nature. 2005; 435: 677-681.

Onken JE, Greer PK, Calingaert B, Hale LP. Bromelain treatment decreases secretion of pro-inflammatory cytokines and chemokines by colon biopsies in vitro. Clinical Immunology. 2008; 126(3): 345-352.

Onken JE, Greer PK, Calingaert B, Hale LP. Bromelain treatment decreases secretion of pro-inflammatory cytokines and chemokine by colon biopsies in vitro. Clin Immunol. 2008; 126: 345-352.

Ota S, Moore S, Stein WH. Preparation and chemical properties of purified stem and fruit bromelains. Biochem. 1964; 3(2):180-185.

Ota S, Muta E, Katahira Y, Okamoto Y. Reinvestigation of fractionation and some properties of the proteolytically active components of stem and fruit bromelains. J Biochem. 1985; 98(1):219-228.

Ozlen SN, Chatsworth C. Cosmetic composition containing alpha hydroxyacids, salicyclic acid, and enzyme mixture of bromelain and papain. United States Patent 5. 1995; 441: 740.

Panagiotis K, Irene K, Styliani K, Maria D.The combination of bromelain and curcumin as an immuneboosting nutraceutical in the prevention of severe COVID-19. Metabolism Open. 2020; 8.

Pavan R, Jain S, Shraddha, Kumar A. Properties and Therapeutic Application of Bromelain: A Review. Biotechnol. Res. Int. 2012; 1(6):1-6.

Philchenkov A. Caspases: potential targets for regulating cell death. J Cell Mol Med. 2004; 8: 432-444.

Pillai K, Akhter J, Chua T C, Morris DL. Anticancer Property of Bromelain with Therapeutic Potential in Malignant Peritoneal Mesothelioma. Cancer Investigation. 2013; 31(4): 241-250.

Rabelo APB, Tambourgi EB, Pessoa A Jr. Bromelain partitioning in two-phase aqueous systems containing PEO-PPO-PEO block copolymers. J Chromatogr. 2004; 807(1): 61-68.

Rao MB, Tanksale AM, Ghatge MS, Deshpande VV. Molecular and biotechnological aspects of microbial proteases. Microbiology and Molecular Biology Reviews. 1998; 62(3):597-635.

Rathnavelu V, Alitheen NB, Sohila S, Kanagesan S, Ramesh R. Potential role of bromelain in clinical and therapeutic applications. Biomedical Reports. 2016; 5(3): 283-288. Rosenberg .Annals of Burns and Fire Disasters. 2015; 4.

Satish S, Ashok KR, William EL, Lucas RS, Surender K, Andy TS, Nitish KM, Chittibabu G, Mara JB, St. Patrick MR, Kenneth WB, Gloria E0, Prakash R. Bromelain inhibits SARS-CoV-2 infection in VeroE6 Cells.BioRxiv. 2020.

Secor ER, Singh A, Guernsey LA, McNamara JT, Zhan L, Maulik N, Thrall RS. Bromelain treatment reduces CD25 expression on activated CD4+ T cells in vitro. International Immunopharmacology. 2009; 9(3): 340-346.

Seligman B. Oral bromelains as adjuncts in the treatment of acute thrombophlebitis. Angiology. 1969; 20: 2226. 
Shahid SK, Turakhia NH, Kundra M, Shanbag P, Daftary GV and Schiess W. Efficacy and safety of phlogenzym - a protease formulation, in sepsis in children. J Assoc Physicians India. 2002; 50: 527-531.

Silva FV, Santos RLA, Fileti AMF. Adaptive control of bromelain precipitation in a fed-batch stirred tank. International Symposium on Advanced Control of Chemical Processes in Gramado; Brazil. 2006.

Silvestre MPC, Carreira RL, Silva MR, Corgosinho FC, Monteiro MRP, Morais HA. Effect of $\mathrm{pH}$ and temperature on the activity of enzymatic extracts from pineapple peel. Food Bioprocess Tech. 2012; 5: 1824-1831.

Smyth RD, Brennan R, Martin GJ. Systemic biochemical changes following the oral administration of a proteolytic enzyme, bromelain. Arch Int Pharmacodyn Ther. 1962; 136: 230-236.

Soares PAG, Vaz AFM, Correia MTS, Pessoa Jr A, Carneiro-da-Cunha MG. Purification of bromelain from pineapple wastes by ethanol precipitation. Sep. Purif. Technol. 2012; 98(19): 389-395.

Stepek G, Buttle DJ, Duce IR, Lowe A and Behnke JM: Assessment of the anthelmintic effect of natural plant cysteine proteinases against the gastrointestinal nematode, Heligmosomoidespolygyrus, in vitro. Parasitology. 2007; 134: 1409-1419.

Stepek G, Lowe AE, Buttle DJ, Duce IR, Behnke JM. In vitro and in vivo anthelmintic efficacy of plant cysteine proteinases against the rodent gastrointestinal nematode, Trichurismuris. Parasitology. 2006; 132(5): 681-689.

Tinozzi S, Venegoni A. Effect of bromelain on serum and tissue levels of amoxicillin. Drugs ExpClin Res.
1978; 4: 39-44.

Tománková 0, Kope冈ný J. Prediction of feed protein degradation in the rumen with bromelain. Anim Feed SciTechnol. 1995; 53(1): 71-80.

Tysnes BB, Maurert HR, Porwol T, Probst B, Bjerkvig R, Hoover F. Bromelain Reversibly Inhibits Invasive Properties of Glioma Cells. Neoplasia. 2001; 3(6): 469-479.

Uhlig G, Seifert J. The effect of proteolytic enzymes (traumanase) on post traumatic edema. Fortschr Med. 1981; 99: 554-556.

Walker AF, Bundy R, Hicks SM, Middleton RW. Bromelain reduces mild acute knee pain and improves well being in a dose-dependent fashion in an open study of otherwise healthy adults. Phytomedicine. 2002; 9: 681-686.

Wallace JM. Nutritional and botanical modulation of the inflammatory cascade - eicosanoids, cyclooxygenases, and lipoxygenases - as an adjunct in cancer therapy. Integr Cancer Ther. 2002; 1: 7-37.

Wu SY, Hu W, Zhang B, Liu S, Wang JM,Wang AM. Bromelain ameliorates the wound microenvironment and improves the healing of firearm wounds. J Surg Res. 2012; 176: 503-509.

Wu W, Ng HS, Sun I, Lan JC. Single step purification of bromelain from Ananas comosus pulp using a polymer/ salt aqueous biphasic system. J. Taiwan Inst. Chem. Eng. 2017; 79: 158-162.

Yamada F, Takahashi N, Murachi T. Purification and characterization of a proteinase from pineapple fruit, fruit bromelain FA2. J Biochem 1976; 79(6), 12231234. 